\title{
Review Article \\ Midline Cervical Cleft: Review of an Uncommon Entity
}

\author{
Liana Puscas \\ Division of Otolaryngology-Head and Neck Surgery, Department of Surgery, Duke University, P.O. Box 3805, Durham, NC 27710, USA
}

Correspondence should be addressed to Liana Puscas; liana.puscas@duke.edu

Received 27 October 2014; Accepted 15 March 2015

Academic Editor: Alessandro Mussa

Copyright (C) 2015 Liana Puscas. This is an open access article distributed under the Creative Commons Attribution License, which permits unrestricted use, distribution, and reproduction in any medium, provided the original work is properly cited.

\begin{abstract}
Introduction. Midline cervical cleft is a rare congenital malformation which nonetheless has a classic presentation. This study presents one of the largest single series of new patients with MCC and provides an exhaustive review and catalogue of publications from the international literature. Materials and Methods. Retrospective chart review performed in two academic medical centers and literature review performed with primary verification of all quoted references. Results. Ten patients with MCC were identified ( 8 boys and 2 girls). All patients presented with the classic findings of this congenital anomaly, and the length of the skin defect correlated with an increase in the patient's age. Surgical excision was complete in all cases. Thorough international literature review yielded only 195 verifiable previously reported cases. Conclusions. This is one of the largest series of new patients with midline cervical cleft presented in the world literature. Although rare (with less than 200 cases published to date) this entity does have a reliable presentation that should lead to rapid and accurate diagnosis. Complete surgical excision at an early age is appropriate since the anomaly increases in length commensurate with the patient's age.
\end{abstract}

\section{Introduction}

Midline cervical cleft (MCC) is a rare congenital anomaly whose embryological origin is uncertain. Review of the international literature reveals at least 195 cases reported to date (not including the 10 patients in this series). Taken together, the information from previously published case reports has shown relatively consistent anatomic and pathologic findings, but there have been few series with more than several patients, and no one has undertaken a review of all the published literature. The purpose of this study was to evaluate the physical and pathologic findings associated with this condition and to provide a comprehensive catalogue of published cases in the world's literature. The findings in this large series of ten patients illustrate the clinical and operative findings, demographics, and treatment of this unusual entity.

\section{Materials and Methods}

This study was performed as a retrospective chart review of patients treated by the University of Southern California Keck School of Medicine Department of OtolaryngologyHead and Neck Surgery and the Duke University Division of
Otolaryngology-Head and Neck Surgery. Ten patients having the clinical and pathologic diagnosis of midline cervical cleft were identified. IRB approval was obtained from both USC and Duke. The charts were reviewed for history, clinical and pathologic findings as well as timing of surgical intervention and postoperative complications. Complete surgical excision of all components of the cleft was performed in every patient, and closure of the surgical wound was achieved using simple vertical closure or single versus multiple Z- or W-plasties depending on the length of the incision and the laxity of the neck tissue.

The literature search was performed by using the search terms "midline cervical cleft" and "congenital midline cervical cleft" in PubMed and then performing an exhaustive review of all possible publications (journal articles, textbook chapters, doctoral dissertations, and case reports) and references. Copies of original manuscripts were obtained from library and internet resources although it was not possible to acquire some dissertations. In these cases, utilizing email communication, librarians provided the number of new cases described in the dissertation. Whenever possible, authors were contacted directly to clarify whether or not cases had been previously reported and in some cases to provide the gender of the patients. If no information was available on 


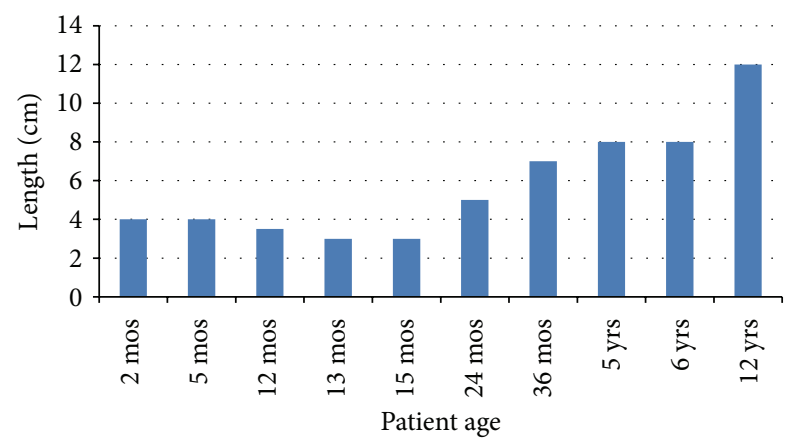

FIGURE 1: Length of involved skin relative to patient age.

a reference, the publication was not included in the table due to the inability to verify the number of new patients with MCC. Information of the gender of the patients was included whenever possible.

\section{Results}

Demographically, in this series, there were eight male and two female patients ranging in age from 2 months to 12 years. Seven children were Hispanic, two were Caucasian with Northern European lineage, and one was of Filipino descent.

Clinically, there were six consistent findings: (1) a midline, vertical atrophic skin defect, (2) a lack of adnexal elements within this skin defect, (3) a superior skin tag, (4) an inferior blind sinus, (5) a midline subcutaneous fibrous cord, and (6) an increase in the size of the defect commensurate with an increase in the patient's age. Mucous could be expressed from almost all of the patients from the inferior sinus. The length of the skin defect ranged from $3 \mathrm{~cm}$ to $12 \mathrm{~cm}$ and there was an almost direct correlation between the age of the patient and the length of the defect (Figure 1). Patients were treated with surgical excision at the time of presentation or at one year of age for those patients who presented prior to their first birthday. The fibrous cord also became more prominent as the age of the patient increased with the older patients having some restriction of neck extension. Postoperatively, one patient had a wound infection that was treated with local wound care and healed without sequelae. There were no recurrences.

Table 1 provides a catalogue of the 195 cases found in the international literature. Author, date of publication, number of cases, and gender are included as well as pertinent notes. Some authors included cases which had been presented before, and in this situation only new patients appear in the table for that publication. Overall, there were 195 cases, 77 females and 58 males and 61 instances of cases presented, but no gender was given. Cases were restricted to the accepted definition of an MCC presentation (superior skin protuberance, midline skin defect, underlying fibrous cord, and inferior blind sinus without involvement of the mandible or sternum). Cases not having at least most of these elements were not included in the final tally.

\section{Discussion}

Every patient in this series presented with the classic findings which define midline cervical cleft: a usually erythematous, vertical, and atrophic skin defect in the midline of the neck which lacks adnexal elements, a subcutaneous fibrous cord which is often longer than the overlying skin defect, a superior skin tag, and an inferior blind sinus. This constellation of clinical findings may be found clearly described in Ombredanne's work in 1949 [1]. Initially in the English literature Bailey in 1925 and Gross in 1940 called this entity "thyroglossal fistula," but their pictures and descriptions are consistent with MCC $[2,3]$. By the time he published on this subject again in 1953, Gross' nomenclature had changed to the term "midline cervical cleft" [4].

Luschka published the first case of MCC in 1848 under the description of "Congenital Fistula of the Neck" (translated) [5]. The drawing in his report is exactly the same as a picture of one of today's patients (Figure 2). In 1864 and 1865, there appeared three reports of neck fistulas by Heusinger but one is more consistent with a bronchogenic cyst (barrel chest, cyanosis, and sinus tract that extends from the left anterior chest toward the lower neck) and the other two have fistula tracts/sinuses involving the lateral aspect of the neck [6]. Those midline cervical clefts are part of a continuum of midline defects which can be seen from two cases that were excluded from the tally: Barsky's case in 1938 in which the patient had a thick midline cord but no epithelial defect [7] and Szenes' case from 1922 in which the cleft in the neck extends inferiorly into the sternum [8].

Early reports indicated a significant preponderance of female patients [9-13], but the inclusion of the new cases presented here helps to narrow the gap between the sexes. In 61 of the cases from the world literature, the gender was not reported. This could have an effect on the gender distribution if most of these cases were found in either girls or boys. There is no apparent explanation for why girls would be affected more than boys if in fact this gender predilection is true. Most patients with MCC do not have a family history of congenital anomalies or other birth defects $[11,14]$, and this was true for the patients in this series as well.

MCC is considered part of the midline branchiogenic syndromes $[15,16]$, but it is not a true cleft in the same way as a cleft palate. Many authors have concluded that incomplete fusion of the second branchial arches is largely responsible for this entity $[11,15,17]$. Several mechanisms have been proposed to explain this incomplete fusion. The presence of amniotic adhesions and vascular anomalies may cause localized tissue ischemia, necrosis, and scarring of the developing branchial arches [18], or pressure on the developing cervical area by the closely juxtaposed pericardial roof during the fifth week of gestation may produce similar results [1]. An underlying mesodermal deficiency [9] or a disturbance in the interaction between the mesoderm and the ectoderm in the developing cervical cleft skin [10] may explain the lack of adnexal elements in the skin defect. One group of authors has proposed that the superior skin tag found in patients with this pathology is formed by a ventral 
TABLE 1: Catalogue of the published world literature by author and year.

\begin{tabular}{|c|c|c|c|c|c|}
\hline Author & Year & Number of pts & $\mathrm{F}$ & M & Comments \\
\hline von Luschka [5] & 1848 & 1 & & 1 & $\begin{array}{c}\text { Picture of the patient in the journal is a classic MCC with } \\
\text { superior skin tag, superficial skin defect overlying a midline } \\
\text { cervical web }\end{array}$ \\
\hline Roth [25] & 1878 & 1 & & 1 & \\
\hline Cusset [26] & 1887 & 1 & 1 & & \\
\hline Arndt [27] & 1888 & 1 & & 1 & $\begin{array}{l}\text { Articles published in } 1889 \text { and } 1892 \text { by Arndt are further } \\
\text { discussions of the same cases but no new cases of midline } \\
\text { cleft/sinuses }\end{array}$ \\
\hline Delkeskamp [28] & 1906 & 1 & & 1 & \\
\hline Bailey [2] & 1925 & 2 & 2 & & $\begin{array}{c}\text { Called "thyroglossal fistula" but picture and description } \\
\text { consistent with MCC }\end{array}$ \\
\hline Nylander [29] & 1928 & 2 & 1 & & \\
\hline Hein [30] & 1931 & 1 & 1 & & \\
\hline Gross and Connerley [3] & 1940 & 2 & 2 & & $\begin{array}{c}\text { Called "thyroglossal fistula" but picture and description } \\
\text { consistent with MCC }\end{array}$ \\
\hline Mouchet [31] & 1942 & 1 & & 1 & \\
\hline Wynn-Williams [32] & 1952 & 2 & 2 & & \\
\hline Gross [4] & 1953 & 4 & 4 & & $\begin{array}{l}\text { It includes the } 2 \text { cases from } 1940 \text { in his total of 6; he calls } \\
\text { them MCC now rather than thyroglossal fistula }\end{array}$ \\
\hline Haym [33] & 1954 & 1 & 1 & & \\
\hline Karfik [34] & 1958 & 2 & & & \\
\hline Maneksha [35] & 1961 & 1 & 1 & & \\
\hline Van Duyn [9] & 1963 & 1 & & 1 & \\
\hline Brown [36] & 1963 & 2 & & & \\
\hline Schaller [37] & 1963 & 1 & & & \\
\hline Cronin and Converse [38] & 1964 & 1 & 1 & & $\begin{array}{l}\text { Same case appears in } 1990 \text { in ch } 39 \text { Deformities of the } \\
\text { Cervical Region in Plastic Surgery, vol. 3, McCarthy JG, ed. } \\
\text { 1990, Philadelphia, WB Saunders, pp. 2078-2085 }\end{array}$ \\
\hline Amr [39] & 1964 & 1 & & 1 & \\
\hline Königová [40] & 1965 & 18 & & & $\begin{array}{c}\text { Article total is } 20 \text { but } 2 \text { were already reported by Karfik in } \\
\text { 1958; same article appears in Czech language in } 1966 \\
\text { Rozhl Chir (the } 1966 \text { article's summary indicates } 22 \text { cases, but } \\
\text { the article text indicates only 20) }\end{array}$ \\
\hline Gottlieb and Lewin [10] & 1966 & 2 & 2 & & \\
\hline Monroe [41] & 1966 & 2 & & & $\begin{array}{l}\text { Passing reference to personal experience of two patients with } \\
\text { fissura colli medialis }\end{array}$ \\
\hline Cosman and Crikelair [15] & 1969 & 2 & & & $\begin{array}{l}\text { In discussion of the continuum of midline branchiogenic } \\
\text { syndromes, } 2 \text { cases of MCC are mentioned }\end{array}$ \\
\hline Kriens and Schuchardt [42] & 1969 & 2 & 1 & 1 & Extensive bibliography and listing of many cases until 1966 \\
\hline Michalland [43] & 1970 & 6 & & & \\
\hline Sanchez Lopez Tello and Straube [44] & 1970 & 1 & & 1 & \\
\hline W. Pirsig and H. Pirsig [45] & 1972 & 1 & & & \\
\hline French and Bale $[46]$ & 1973 & 1 & 1 & & \\
\hline Sanchez Lopez Tello and Mueller [47] & 1973 & 2 & & 2 & \\
\hline Dargallo Reventos [48] & 1975 & 4 & & & $\begin{array}{l}\text { In addition, one "incomplete" case is mentioned that was } \\
\text { entirely superficial without any deeper elements and was } \\
\text { incompletely described so it was excluded from the final tally }\end{array}$ \\
\hline Ohtsuka et al. [49] & 1976 & 1 & & & \\
\hline
\end{tabular}


TABLe 1: Continued.

\begin{tabular}{|c|c|c|c|c|c|}
\hline Author & Year & Number of pts & $\mathrm{F}$ & M & Comments \\
\hline Post $[50]$ & 1976 & 2 & & 2 & \\
\hline Isono et al. [51] & 1977 & 1 & & & \\
\hline Balcells-Par and Sancho-Cerquella [52] & 1977 & 3 & & & \\
\hline Andersen and Svendsen [53] & 1978 & 1 & 1 & & \\
\hline Minami et al. [54] & 1980 & 1 & & 1 & \\
\hline Fritzmeier and Kronsbein [55] & 1982 & 1 & 1 & & \\
\hline Wood and Deister [56] & 1983 & 1 & & 1 & \\
\hline Godbersen and Wiedemann [57] & 1984 & 1 & 1 & & \\
\hline Cotin et al. $[58]$ & 1984 & 1 & & & \\
\hline Lardenet et al. [59] & 1984 & 1 & & 1 & It states 70 cases had been reported in the world literature \\
\hline Gargan et al. [11] & 1985 & 6 & 5 & 1 & $\begin{array}{l}\text { Article total is } 12 \text { because it includes the cases that Gross } \\
\text { reported in } 1940 \text { and } 1953\end{array}$ \\
\hline Soper et al. [60] & 1986 & 1 & & & \\
\hline Breton et al. [61] & 1987 & 4 & & 4 & $\begin{array}{l}\text { Three of the cases are represented in another article } \\
\text { published in } 1989\end{array}$ \\
\hline Godbersen et al. [22] & 1987 & 2 & 1 & 1 & \\
\hline Novák and Jakoubková [62] & 1987 & 1 & & 1 & \\
\hline Massardier [63] & 1987 & 4 & & & \\
\hline Desnos et al. [64] & 1987 & 4 & 4 & & \\
\hline Mihara and Wada [65] & 1987 & 1 & & & \\
\hline Lindsay et al. [66] & 1988 & 2 & & & \\
\hline Bergevin et al. [12] & 1989 & 1 & 1 & & \\
\hline S. G. Fincher and G. G. Fincher [67] & 1989 & 1 & & 1 & \\
\hline Breton and Freidel $[68]$ & 1989 & & & & All 3 cases are included in the 1987 article, no new cases \\
\hline Van der Meulen et al. [69] & 1990 & 1 & & 1 & \\
\hline Raffensperger [70] & 1990 & 1 & & & \\
\hline van der Staak et al. [71] & 1991 & 2 & 1 & 1 & \\
\hline Ikuzawa et al. [24] & 1992 & 1 & 1 & & \\
\hline Nicklaus et al. [72] & 1992 & 2 & 1 & 1 & $\begin{array}{l}\text { It includes a case reported by J Friedberg in Dec } 1989 \text { in Ped } \\
\text { Clinc of North Amer }\end{array}$ \\
\hline Montinet et al. [73] & 1992 & 1 & & 1 & \\
\hline Maddalozzo et al. [17] & 1993 & 5 & 4 & 1 & \\
\hline Liu and Lee [14] & 1994 & 1 & & 1 & \\
\hline Kececi et al. [19] & 1994 & 1 & 1 & & Description consistent with a MCC \\
\hline Maschka et al. [74] & 1995 & 1 & 1 & & \\
\hline Sfeir et al. [75] & 1995 & 4 & & & \\
\hline Ayache et al. [76] & 1997 & 1 & & 1 & \\
\hline Andryk et al. [77] & 1999 & 1 & & 1 & \\
\hline Soderberg et al. [78] & 1999 & 1 & 1 & & \\
\hline Eastlack et al. [79] & 2000 & 1 & & 1 & \\
\hline Çetinkurşun [80] & 2001 & 1 & & 1 & \\
\hline Ercocen $[23]$ & 2002 & 1 & 1 & & \\
\hline Genc et al. [81] & 2002 & 1 & & 1 & \\
\hline Sanchez Lopez Tello [82] & 2002 & 1 & & 1 & $\begin{array}{l}\text { Article total is } 4 \text { but includes cases of Sanchez-Lopes-Tello } \\
\text { reported in } 1970 \text { with Straube and in } 1973 \text { with Muller }\end{array}$ \\
\hline Tsukuno et al. [83] & 2002 & 1 & 1 & & \\
\hline Hirokawa et al. [84] & 2003 & 1 & 1 & & \\
\hline
\end{tabular}


TABLE 1: Continued.

\begin{tabular}{|c|c|c|c|c|c|}
\hline Author & Year & Number of pts & $\mathrm{F}$ & M & Comments \\
\hline Joshi et al. [20] & 2003 & 1 & 1 & & \\
\hline Mylnarek et al. [85] & 2003 & 1 & 1 & & \\
\hline Daw and Patel [86] & 2003 & 1 & & 1 & \\
\hline Sannajust et al. [87] & 2004 & 1 & 1 & & \\
\hline Derbez et al. [88] & 2004 & 5 & 3 & 2 & \\
\hline Bajaj et al. [89] & 2004 & 1 & & 1 & \\
\hline Tagliarini et al. [90] & 2004 & 2 & 1 & 1 & \\
\hline Gardner and Moss [91] & 2005 & 1 & & 1 & \\
\hline Saha et al. [13] & 2005 & 2 & 1 & 1 & \\
\hline Cochran et al. [92] & 2006 & 1 & 1 & & \\
\hline C.O. Kara and I.G. Kara [93] & 2006 & 1 & & 1 & \\
\hline Foley and Fallat [94] & 2006 & 1 & & & \\
\hline Smith et al. [95] & 2006 & 3 & 2 & 1 & \\
\hline Agag et al. [96] & 2007 & 1 & & 1 & \\
\hline Mendis and Moss [97] & 2007 & 2 & 1 & 1 & \\
\hline Franzese et al. [98] & 2008 & 2 & 2 & & \\
\hline Turkyilmaz et al. [99] & 2008 & 1 & & & \\
\hline Cheng and Gottschall [100] & 2009 & 1 & 1 & & \\
\hline Renukaswamy et al. [101] & 2009 & 4 & 1 & 3 & \\
\hline Sharma et al. [102] & 2009 & 1 & & 1 & \\
\hline Vure et al. [103] & 2009 & 1 & 1 & & \\
\hline Warden and Millar [104] & 2010 & 1 & 1 & & \\
\hline Nijkamp and Rijlaarsdam [105] & 2011 & 1 & 1 & & \\
\hline Patil et al. [106] & 2011 & 1 & 1 & & \\
\hline Grynspan et al. [107] & 2012 & 1 & & 1 & \\
\hline Jakobsen et al. [108] & 2012 & 1 & 1 & & It presents 3 cases but two involved the mandible \\
\hline McInnes et al. [109] & 2012 & 1 & & 1 & \\
\hline Doddamani et al. [110] & 2012 & 1 & 1 & & \\
\hline Mendez-Gallart et al. [111] & 2012 & 1 & 1 & & \\
\hline Sinopidis et al. [112] & 2012 & 1 & 1 & & \\
\hline Tröbs et al. [113] & 2012 & 2 & & 2 & \\
\hline Martí Fajardo [114] & 2012 & 1 & & 1 & \\
\hline Lillehei and Coran [115] & 2012 & 1 & 1 & & \\
\hline Farhadi et al. [116] & 2012 & 2 & 1 & 1 & \\
\hline Mirza [117] & 2013 & 1 & & 1 & \\
\hline Saha et al. [118] & 2013 & 2 & 2 & 0 & $\begin{array}{l}\text { It includes two cases initially described in Saha's } 2005 \text { paper; } \\
\text { a case of a true cleft from the mandible to the sternum was } \\
\text { excluded from the tally }\end{array}$ \\
\hline Eom et al. [119] & 2014 & 1 & 1 & 0 & First case reported in the Korean population \\
\hline Crippa et al. [120] & 2014 & 1 & 1 & 0 & \\
\hline Puscas (new cases) & 2015 & 10 & 2 & 8 & \\
\hline TOTAL & & 205 & 79 & 66 & \\
\hline
\end{tabular}

outgrowth of tongue muscle [12]. Some have proposed that MCC is an inferior presentation of Tessier's facial cleft \#30 which is a cleft of the mandible [19-21]. Karík included MCC under the category of branchiogenic disorders along with disorders of the mandible, tongue, lower lip, and thorax [16]. Others have proposed that MCC represents a developmental field defect $[22,23]$. Bergevin et al. concluded that the surface in MCC is an invagination of endodermal cells [12] whereas Ikuzawa et al. felt that MCC formed because the median sulcus had closed insufficiently allowing a migration of aberrant multipotential cells from which the various pathologic elements of MCC are derived [24].

MCC has been associated with thyroglossal duct and branchial cysts and possibly with accessory bronchi 


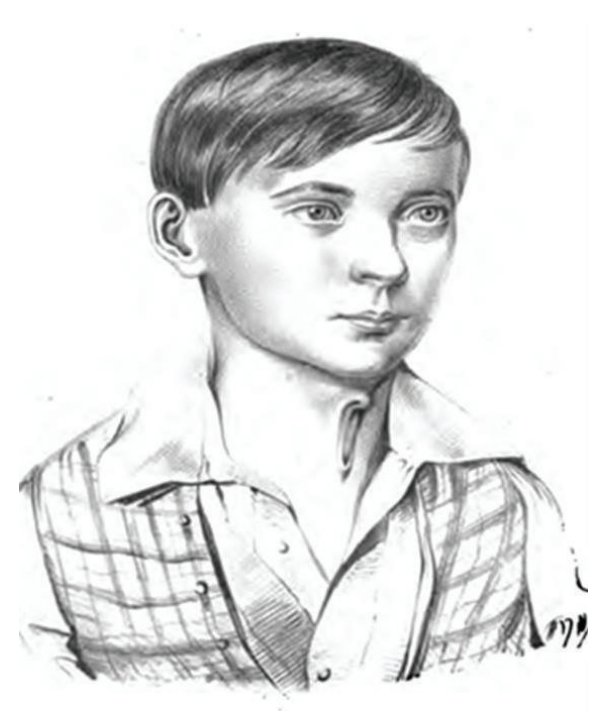

(a)

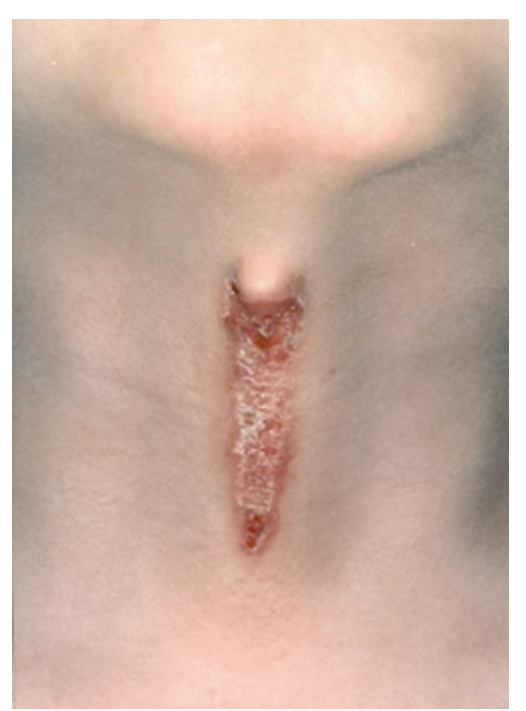

(b)

FIgURE 2: Consistency of presentation between a patient from 1848 (a) and the modern day (b).

$[46,77,97]$. Indeed, MCC must be correctly diagnosed on pathology to differentiate it from a bronchogenic cyst which can also present as a midline atrophic skin defect with a sinus tract that weeps mucous or serous fluid. Pathologically, a bronchogenic cyst has a lining of pseudostratified ciliated columnar epithelium and often has accessory tissue such as smooth muscle, seromucinous glands, and sometimes cartilage, thus resembling a very immature bronchus [121]. However, the constellation of clinical and pathologic findings can distinguish between the two entities. The erythematous, linear, and atrophic skin defect of MCC can mimic other skin disorders such as linear scleroderma, but linear scleroderma lacks the other salient characteristics of MCC [111].

Pathologic examination of the specimens from the 10 new patients presented here revealed the typical findings: the presence of skeletal muscle, minor salivary gland elements, lymphoid tissue and connective tissue, and the absence of adnexal skin elements such as hair or sebaceous glands. Sinopidis and colleagues present a very good tabular summary of the pathologic description of the individual MCC elements: the cephalic skin tag contains stratified squamous epithelium and striated muscle, the atrophic skin defect is comprised of stratified squamous epithelium without adnexal structures but with bundles of striated muscle in the dermis, and the caudal duct has squamous epithelium superficially but pseudostratified ciliated epithelium more deeply along with seromucinous glands [112].

At birth, the external layer of the cleft may consist of a weeping, red membrane which then heals to produce cicatricial skin as the patient grows. The fibrous cord, which usually extends down to the pretracheal fascia as it did in these patients, also becomes more prominent as the child grows. This is because the affected tissues lag behind in vertical growth compared with the surrounding normal neck tissue. Those patients in whom the cord is apparent even without neck extension have difficulty extending their necks. When the fibrous cord extends to the level of the mandible, a bony spur is often seen on the anterior, inferior surface of the bone secondary to the traction placed on the mandible by this tethering cord which may be severe enough to produce an open bite deformity [11, 19, 91, 102, 111].

This case series clearly demonstrates an important finding which impacts the timing of intervention in these patients. There was almost a direct correlation between the patient's age and the length of the defect (Figure 1). Whereas some previous publications recommended early excision only in those patients in whom the fibrous cord was prominent and severe producing inability to extend the neck or remodeling of the mandible [10, 11], early excision is recommended to prevent an increased scar length as well as the problems associated with a tethering midline cord $[106,111]$. We treated patient surgically at the time of presentation for those over the age of one year and waited until age one for those who presented very early in life.

It is also important to completely excise the lesion. Simply transecting the fibrous cord or performing incomplete excision of the cutaneous and subcutaneous elements leads to recurrence [9-11, 74]. Closure of the surgical defect is performed with a simple vertical closure if the defect is not long and the surrounding skin is lax. The use of single or multiple $\mathrm{W}$ - or Z-plasties is recommended for longer defects to break up the scar and improve the cosmetic and functional results. This has long been proposed as the best way to deal with the vertical defect created by excision of the MCC and has become the usual way in which many patients are closed [40]. Early some patients with a long defect treated with a vertical closure developed neck contractures and an open bite deformity secondary to scarring after the surgery [11].

\section{Conclusion}

This case series demonstrates two interesting points. First, there was a preponderance of male patients (8/10) in contrast to previous case series in which females have predominated. 
Second, since the length of the defect increased as the patient's age increased, early excision of the lesion to minimize scarring is recommended. The catalogue of cases from the world literature also provides an organized list that may be helpful for future research.

\section{Conflict of Interests}

The author declares that there is no conflict of interests regarding the publication of this paper.

\section{Acknowledgments}

The author would like to thank Dale Rice, MD, Professor, University of Southern California, Department of Otolaryngology-Head and Neck Surgery, and Dennis Crockett, MD, of Head/Neck Associates of Orange County, for their help in acquiring patient data; $\mathrm{H}$. Wolfgang Beumer, MD, for his invaluable help in translating the German language articles; and Stephen Perlman from the Durham VA Library for his help in acquiring articles from other institutions. None of them received any compensation for their contributions, but their help was greatly appreciated.

\section{References}

[1] L. Ombredanne, Precis Clinique et Operatoire de Chirurgie Infantile, Masson, Paris, France, 5th edition, 1949.

[2] H. Bailey, "Thyroglossal cysts and fistulæ," British Journal of Surgery, vol. 12, no. 47, pp. 579-589, 1925.

[3] R. E. Gross and M. L. Connerley, "Thyroglossal cysts and sinuses," The New England Journal of Medicine, vol. 223, no. 16, pp. 616-624, 1940.

[4] R. E. Gross, The Surgery of Infancy and Childhood, WB Saunders, Philadelphia, Pa, USA, 1953.

[5] H. von Luschka, "Ueber fistula colli congenita," Archiv für Physiologische Heilkunde, vol. 7, pp. 24-27, 1848.

[6] C. F. Heusinger, "Zu den Halskiemenbogenresten," Virchows Archiv A: Pathological Anatomy and Histology, vol. 29, pp. 358380, 1864.

[7] A. J. Barsky, Plastic Surgery, W. B Saunders Company, Philadelphia, Pa, USA, 1938.

[8] A. Szenes, "Uber die fissura sterni und ihre entstehung," Archiv für klinishce Chirurgie, vol. 119, pp. 116-125, 1922.

[9] J. van Duyn, "Congenital midline cervical cord with report of a case and a note on the etiology of congenital torticollis," Plastic and reconstructive surgery, vol. 31, no. 6, pp. 576-586, 1963.

[10] E. Gottlieb and M. L. Lewin, "Congenital midline cervical clefts of neck," New York State Journal of Medicine, vol. 66, pp. 712-718, 1966.

[11] T. J. Gargan, M. McKinnon, and J. B. Mulliken, "Midline cervical cleft," Plastic and Reconstructive Surgery, vol. 76, no. 2, pp. 225229, 1985.

[12] M. A. Bergevin, S. Sheft, C. Myer III, and A. J. McAdams, "Congenital midline cervical cleft," Pediatric Pathology, vol. 9, no. 6, pp. 731-739, 1989.

[13] S. Saha, S. Misra, V. P. Saha, and A. R. Mondal, "Midline cervical cleft: a report of two cases," Indian Journal of Otolaryngology and Head and Neck Surgery, vol. 57, no. 1, pp. 78-79, 2005.
[14] K. K. W. Liu and K. H. Lee, "Congenital midline cervical clefta rare clinical entity," Otolaryngology-Head and Neck Surgery, vol. 111, no. 1, pp. 148-149, 1994.

[15] B. Cosman and G. F. Crikelair, "Midline branchiogenic syndromes," Plastic and Reconstructive Surgery, vol. 44, no. 1, pp. 41-48, 1969.

[16] V. Karík, "Proposed classification of rare congenital cleft malformations in the face," Acta Chirurgiae Plasticae, vol. 8, no. 3, pp. 163-168, 1966.

[17] J. Maddalozzo, A. Frankel, and L. D. Holinger, "Midline cervical cleft," Pediatrics, vol. 92, pp. 286-287, 1993.

[18] F. Braithwaite and J. Watson, "A report on three unusual cleft lips," British Journal of Plastic Surgery, vol. 2, no. 1, pp. 38-49, 1949.

[19] Y. Kececi, R. Gencosmanoglu, C. Gorken, and A. Cagdas, "Facial cleft no. 30," Journal of Craniofacial Surgery, vol. 5, no. 4, pp. 263-264, 1994.

[20] A. Joshi, G. Chimanchode, and M. Jagannathan, "Congenital midline cervical web causing neck contracture as an isolated deformity," European Journal of Plastic Surgery, vol. 26, no. 7, pp. 373-374, 2003.

[21] P. Tessier, "Anatomical classification of facial, cranio facial and latero facial cleft," Journal of Maxillofacial Surgery, vol. 4, no. 2, pp. 69-92, 1976.

[22] S. Godbersen, V. Heckel, and H. R. Wiedemann, "Pterygium colli medianum and midline cervical cleft: midline anomalies in the sense of a developmental field defect," American Journal of Medical Genetics, vol. 27, no. 3, pp. 719-723, 1987.

[23] A. R. Ercocen, S. Yilmaz, and H. Aker, "Congenital midline cervical cleft: case report and review," Journal of Oral and Maxillofacial Surgery, vol. 60, no. 5, pp. 580-585, 2002.

[24] M. Ikuzawa, K. Matsumoto, K. Amino, and M. Sakuda, "Midline cervical cleft-a case report," International Journal of Oral and Maxillofacial Surgery, vol. 21, pp. 258-259, 1992.

[25] M. Roth, "Ein Fall von Halskiemenfistel," Virchows Archiv, vol. 72, no. 3, pp. 444-445, 1878 .

[26] J. Cusset, "Kystes et Fistules d'Origine branchiale," in Congres Francais de Chirurgie 1886, Session 2, pp. 553-563, Paris, France, 1887.

[27] R. Arndt, "Zur Lehre von den Fistulae colli congenitae," Berliner Klinische Wochenschrift, vol. 25, pp. 741-744, 1888.

[28] G. Delkeskamp, "Über die kongenitale, unvollständige, äußere, mediane Halsfistel," Deutsche Zeitschrift für Chirurgie, vol. 84, no. 1-3, pp. 251-256, 1906.

[29] P. E. A. Nylander, Beitraäge zur Kenntnis der Kongenitalen Halsfisteln und -Zysten : [Akad. avh.Hfors.], vol. 5, Pathologischen Institut der Universitat Helsingfors, Helsinki, Finland, 1928.

[30] G. Hein, Vogelgesichtsbildung im Zusammenhang mit einer kongenitalenmedianen Halsfistel [M.Ed. Dissertation], 1931.

[31] A. Mouchet, "Fistule Congenitale du CouSusternale," Paris Med, vol. 86, no. 43, p. 332, 1942.

[32] D. Wynn-Williams, "Congenital midline cervical cleft and web," British Journal of Plastic Surgery, vol. 5, no. 2, pp. 87-93, 1949.

[33] J. Haym, "Halsfisteln und Halszysten," Stoma, vol. 7, no. 3, pp. 145-154, 1954.

[34] V. Karfik, "Fissura colli medialis," Vojenské Zdravotnické Listy, vol. 27, pp. 104-108, 1958.

[35] R. J. Maneksha, "Congenital midline cervical cleft with a possible thyro-glossal cyst," British Journal of Plastic Surgery, vol. 14, p. 32, 1961. 
[36] J. J. M. Brown, Surgery of Childhood, edited by J. J. M. Brown, Williams \& Wilkins, Baltimore, Md, USA, 1963.

[37] G. A. Schaller, Uber congenitale mediale Halsfisteln und czysten [MEd Dissertation], 1963.

[38] T. D. Cronin, "Deformities of the cervical region," in Reconstructive Plastic Surgery, J. M. Converse, Ed., chapter 30, p. 1190, W.B. Saunders, Philadelphia, Pa, USA, 1964.

[39] M. Amr, "Cervical cysts, sinuses, and fistul high symbol of branchial, pharyngothymic duct, and thyroglossal duct origin," British Journal of Plastic Surgery, vol. 17, no. 2, pp. 148-167, 1964.

[40] R. Königová, "Fissura colli medialis," Acta Chirurgiae Plasticae, vol. 7, no. 4, pp. 270-280, 1965.

[41] C. W. Monroe, "Midline cleft of the lower lip, mandible and tongue with flexion contracture of the neck: case report and review of the literature," Plastic and Reconstructive Surgery, vol. 38, no. 4, pp. 312-319, 1966.

[42] O. Kriens and K. Schuchardt, "Die oberflachliche medianehalsspalte," Chir Plastic Reconst, vol. 6, pp. 235-254, 1969.

[43] G. Michalland, Contribution a l'etude des Fissures Mentosternales et des Brides Cervicales Medianes [A Propos de Six Cas These Med], 1970.

[44] C. Sanchez Lopez Tello and K. Straube, "Hendidura superficialmedia del cuello," Bol Soc Cast Ast Leon Pediat, vol. 11, p. 401, 1970.

[45] W. Pirsig and H. Pirsig, "Die angeborene oberflachliche mediane halsspalte [congenital midline cervical cleft]," HNO, vol. 20, no. 1, pp. 15-18, 1972.

[46] W. E. French and G. F. Bale, "Midline cervical cleft of the neck with associated branchial cyst," The American Journal of Surgery, vol. 125, no. 3, pp. 376-381, 1973.

[47] C. Sanchez Lopez Tello and I. Mueller, "Beitrag zur oberflachlichen medianen Halsspalte," Klinische Padiatrie, vol. 185, no. 4, pp. 307-312, 1973.

[48] J. Dargallo Reventos, "Hendidura superficial media del cuello," Barcelona Quirurgica, vol. 19, no. 1, pp. 33-36, 1975.

[49] H. Ohtsuka, H. Ueishi, M. Itoh et al., "Congenital midline cervical cleft-a case report," Japanese Journal of Plastic and Reconstructive Surgery, vol. 19, no. 6, pp. 573-577, 1976 (Japanese).

[50] H. J. Post, Uber seltene embryogene Missbildungen des Halses [Inaugural Dissertation], Klinik Dr. Schweckendiek, 1976.

[51] T. Isono, K. Niitsu, and K. Endoh, "Congenital midline cervical cleft of infants-a case report," Japanese Journal of Pediatrics, vol. 30, pp. 1583-1586, 1977.

[52] R. Balcells-Par, V. Sancho-Cerquella et al., "Fente Mediane Congenitaledu Cou," Annales de Chirurgie Infantile, vol. 18, no. 2, pp. 149-155, 1977.

[53] B. L. Andersen and E. P. Svendsen, "Midline cervical clefts: case report," Scandinavian Journal of Plastic and Reconstructive Surgery, vol. 12, no. 2, pp. 169-170, 1978.

[54] R. T. Minami, J. Pletcher, and R. L. Dakin, "Midline cervical cleft: a case report," Journal of Maxillofacial Surgery, vol. 8, no. 1, pp. 65-68, 1980.

[55] F. Fritzmeier and H. Kronsbein, "Klinik und Pathogenese der medianen Halsspalte. Ein Beitrag zur Differentialdiagnose der Halsfisteln," HNO, vol. 30, no. 1, pp. 37-42, 1982.

[56] G. A. Wood and E. Deister, "Anterior midline neck webbing with microgenia and symphyseal exostosis," Oral Surgery, Oral Medicine, Oral Pathology, vol. 56, no. 2, pp. 128-131, 1983.

[57] S. Godbersen and H. R. Wiedemann, "Pterygium colli medianum," EL PAÍS, vol. 3, p. 22, 1984.
[58] G. Cotin, N. Garabedian, F. Leprechey, M. Bodard, and M. Menard, "Kystes et fistules cervicaux dorigine branchiale. Etude embryologique, clinique et thérapeutique," Annales de Pédiatrie, vol. 31, no. 11, pp. 953-958, 1984.

[59] J. Lardenet, C. Simon, and M. Wayoff, "Fistule MentoSternale-a propos d'un cas," Journal Français d'Oto-RhinoLaryngologie, vol. 33, no. 8, pp. 418-419, 1984.

[60] R. T. Soper and K. C. Pringle, "Cysts and sinuses of the neck," in Pediatric Surgery, K. J. Welch, J. G. Randolph, and M. M. Ravitch, Eds., chapter 54, pp. 539-552, Year Book Medical Publishers, Chicago, Ill, USA, 4th edition, 1986.

[61] P. Breton, H. Dodat, and M. Freidel, "Un Syndrome Malfromatif Cervical Rare: La Fissure Mento-Sternale," Chirurgie Pédiatrique, vol. 28, no. 3, pp. 170-174, 1987.

[62] J. Novák and S. Jakoubková, "Fissura colli medialis," Ceskoslovenska Otolaryngologie, vol. 36, no. 2, pp. 116-120, 1987.

[63] A. Massardier, Les Brides Cervicales Medianes Congenitales [These Med], 1987.

[64] J. Desnos, J. Dubin, and V. Darsonval, "Fissure mediane congenitale du cou," Journal Français d'Oto-Rhino-Laryngologie, vol. 36, no. 1, pp. 35-38, 1987.

[65] K. Mihara and H. Wada, "Midline cervical cleft," Nishi Nihon Hifuka, vol. 49, no. 5, pp. 808-811, 1987.

[66] W. K. Lindsay, “The neck," in Plastic Surgery in Infancy and Childhood, J. C. Mustarde and I. T. Jackson, Eds., chapter 25, pp. 435-449, Churchill Livingstone, New York, NY, USA, 3rd edition, 1988.

[67] S. G. Fincher and G. G. Fincher, "Congenital midline cervical cleft with subcutaneous fibrous cord," Otolaryngology-Head and Neck Surgery, vol. 101, no. 3, pp. 399-401, 1989.

[68] P. Breton and M. Freidel, "Bride cervicale mediane congenitale," Annales de Chirurgie Plastique et Esthétique, vol. 34, no. 1, pp. 73-76, 1989.

[69] J. Van der Meulen, R. Mazzola, M. Stricker, and B. Raphael, "Classification of craniofacial malformations," in Craniofacial Malformations, M. Stricker, J. C. van der Meulen, B. Raphael, and R. Mazzola, Eds., p. 225, Churchill Levingstone, London, UK, 1990.

[70] J. G. Raffensperger, "Congenital cysts and sinuses of the neck," in Swenson's Pediatric Surgery, J. G. Raffernsperger, Ed., chapter 22, pp. 187-188, Appleton \& Lange, Norwalk, Conn, USA, 5th edition, 1990.

[71] F. H. J. van der Staak, M. Pruszczynski, R. S. V. M. Severijnen, C. A. van de Kaa, and C. Festen, "The midline cervical cleft," Journal of Pediatric Surgery, vol. 26, no. 12, pp. 1391-1393, 1991.

[72] P. J. Nicklaus, V. Forte, and J. Friedberg, "Congenital mid-line cervical cleft," Journal of Otolaryngology, vol. 21, no. 4, pp. 241243, 1992.

[73] B. Montinet, L. Sibeoni, and M. Dellandrea, "Fistule MentoSternale," Journal Français d'Oto-Rhino-Laryngologie, vol. 41, no. 2, pp. 139-144, 1992.

[74] D. A. Maschka, J. E. Clemons, and J. F. Janis, "Congenital midline cervical cleft-case report and review," Annals of Otology, Rhinology and Laryngology, vol. 104, no. 10, pp. 808811, 1995.

[75] R. Sfeir, V. Martinot, M. Lecomte-Houcke, B. Defauw, P. Pellerin, and P. Debeugny, "Fistules mento-sternales. Revue de la littérature. A propos de quatre cas," Annales de Chirurgie Plastique Esthétique, vol. 40, no. 2, pp. 176-181, 1995. 
[76] D. Ayache, V. Ducroz, G. Roger, and E. N. Garabedian, "Case report-midline cervical cleft," International Journal of Pediatric Otorhinolaryngology, vol. 40, pp. 189-193, 1997.

[77] J. E. Andryk, J. E. Kerschner, R. T. Hung, J. J. Aiken, and S. F. Conley, "Mid-line cervical cleft with a bronchogenic cyst," International Journal of Pediatric Otorhinolaryngology, vol. 47, no. 3, pp. 261-264, 1999.

[78] K. C. Soderberg, J. M. Key, and D. M. Parham, "Quiz case 1 (Pathology Forum)," Archives of Otolaryngology-Head and Neck Surgery, vol. 125, no. 12, pp. 1398-1400, 1999.

[79] J. P. Eastlack, R. M. Howard, and I. J. Frieden, "Congenital midline cervical cleft: case report and review of the English language literature," Pediatric Dermatology, vol. 17, no. 2, pp. $118-122,2000$.

[80] S. Çetinkurşun, S. Demirbağ, H. Öztürk, I. Sürer, and M. T. Sakarya, "Congenital midline cervical cleft," Clinical Pediatrics, vol. 40, no. 6, pp. 363-364, 2001.

[81] A. Genc, C. Taneh, O. A. Arslan et al., "Congenital midline cervical cleft: a rare embryopathogenic disorder," European Journal of Plastic Surgery, vol. 25, pp. 29-31, 2002.

[82] C. Sanchez Lopez Tello, M. A. Mingorance, J. C. V. Mendias, and R. Luque, "Hendidura superficial media de cuello," Cirugía Pediátrica, vol. 15, pp. 110-113, 2002.

[83] M. Tsukuno, Y. Kita, and K. Kurihara, "A case of midline cervical cleft," Congenital Anomalies, vol. 42, no. 2, pp. 143-145, 2002.

[84] S. Hirokawa, H. Uotani, H. Okami, K. Tsukada, T. Futatani, and I. Hashimoto, "A case of congenital midline cervical cleft with congenital heart disease," Journal of Pediatric Surgery, vol. 38, no. 7, pp. 1099-1101, 2003.

[85] A. Mlynarek, A. Hagr, T. L. Tewfik, and V. H. Nguyen, "Congenital mid-line cervical cleft: Case report and review of literature," International Journal of Pediatric Otorhinolaryngology, vol. 67, no. 11, pp. 1243-1249, 2003.

[86] J. L. Daw Jr. and P. K. Patel, "Double-opposing Z-plasty for correction of midline cervical web," The Journal of Craniofacial Surgery, vol. 14, no. 5, pp. 774-778, 2003.

[87] J. P. Sannajust, I. Barthelemy, C. Evering, I. Mandard, and J.M. Mondie, "Fente cervicale médiane congénitale," Revue de Stomatologie et de Chirurgie Maxillo-Faciale, vol. 105, no. 6, pp. 338-341, 2004.

[88] R. Derbez, R. Nicollas, S. Roman, A. Estève, and J. M. Triglia, "Congenital midline cervical cleft of the neck: a series of five cases," International Journal of Pediatric Otorhinolaryngology, vol. 68, no. 9, pp. 1215-1219, 2004.

[89] Y. Bajaj, D. Dunaway, and B. E. J. Hartley, "Surgical approach for congenital midline cervical cleft," Journal of Laryngology and Otology, vol. 118, no. 7, pp. 566-569, 2004.

[90] J. V. Tagliarini, E. C. Castilho, and J. C. Montovani, "Fenda cervical mediana (midline cerivcal cleft)," Revista Brasileira de Oto-Rino-Laringologia, vol. 70, no. 4, pp. 705-709, 2004.

[91] R. O. E. Gardner and A. L. H. Moss, "The congenital cervical midline cleft. Case report and review of literature," British Journal of Plastic Surgery, vol. 58, no. 3, pp. 399-403, 2005.

[92] C. S. Cochran, R. J. DeFatta, and A. C. Brenski, "Congenital midline cervical cleft: a practical approach to Z-plasty closure," International Journal of Pediatric Otorhinolaryngology, vol. 70, no. 3, pp. 553-559, 2006.

[93] C. O. Kara and I. G. Kara, "Congenital midline cervical cleft," Otolaryngology-Head and Neck Surgery, vol. 135, no. 6, pp. 953-954, 2006.
[94] D. S. Foley and M. E. Fallat, "Thyroglossal duct and other congenital midline cervical anomalies," Seminars in Pediatric Surgery, vol. 15, no. 2, pp. 70-75, 2006.

[95] R. M. Smith Jr., P. C. Barth, J. Castillo, B. Millman, and W. E. Wood, "Congenital midline cervical cleft: a report of 3 cases," Ear, Nose \& Throat Journal, vol. 85, no. 2, pp. 119-125, 2006.

[96] R. Agag, J. Sacks, and L. Silver, "Congenital midline cervical cleft," Cleft Palate-Craniofacial Journal, vol. 44, no. 1, pp. 98-101, 2007.

[97] D. Mendis and A. L. H. Moss, "Case series: variations in the embryology of congenital midline cervical clefts," Acta Chirurgiae Plasticae, vol. 49, no. 3, pp. 71-74, 2007.

[98] C. Franzese, J. D. Hayes, and K. Nichols, "Congenital midline cervical cleft: a report of two cases," Ear, Nose and Throat Journal, vol. 87, no. 3, pp. 166-168, 2008.

[99] Z. Türkyilmaz, R. Karabulut, Y. A. Bayazit et al., "Congenital neck masses in children and their embryologic and clinical features," B-ENT, vol. 4, no. 1, pp. 7-18, 2008.

[100] S. S. Cheng and J. A. Gottschall, "Double opposing Z-plasty for congenital midline cervical web: a case report," International Journal of Pediatric Otorhinolaryngology Extra, vol. 4, no. 3, pp. 123-128, 2009.

[101] G. M. Renukaswamy, M. A. Soma, and B. E. J. Hartley, "Midline cervical cleft: a rare congenital anomaly," Annals of Otology, Rhinology and Laryngology, vol. 118, no. 11, pp. 786-790, 2009.

[102] U. Sharma, M. M. Mehta, and V. Y. Bhatia, "Congenital midline cervical cleft presenting as neck contracture," European Journal of Plastic Surgery, vol. 32, no. 5, pp. 263-266, 2009.

[103] S. Vure, K. Pang, L. Hallam, M. Lui, and D. Croaker, “Congenital midline cervical cleft with an underlying bronchogenic like cyst," Pediatric Surgery International, vol. 25, no. 9, pp. 811-813, 2009.

[104] C. Warden and A. J. W. Millar, "A rare congenital midline cervical cleft," South African Journal of Surgery, vol. 48, no. 3, pp. 98-99, 2010.

[105] A. Nijkamp and R. Rijlaarsdam, "A neonate with a red line in the neck," Nederlands Tijdschrift voor Geneeskunde, vol. 155, no. 18, article A2299, 2011.

[106] S. B. Patil, S. M. Kale, M. Math, and N. Khare, "Congenital midline cervical cleft leading to contracture of neck," Indian Journal of Plastic Surgery, vol. 44, no. 3, pp. 509-510, 2011.

[107] D. Grynspan, Y. Ying, E. Nizalik, K. Cowan, J. De Nanassy, and S. Chou, "A forme-fruste variant of congenital midline cervical cleft with hamartomatous adnexal elements managed without Z-plasty," Pediatric and Developmental Pathology, vol. 15, no. 3, pp. 245-248, 2012.

[108] L. P. Jakobsen, P. Pfeiffer, M. Andersen et al., "Genetic studies in congenital anterior midline cervical cleft," American Journal of Medical Genetics Part A, vol. 158, no. 8, pp. 2021-2026, 2012.

[109] C. W. McInnes, A. D. Benson, C. G. Verchere, J. P. Ludemann, and J. S. Arneja, "Management of congential midline cervical cleft," Journal of Craniofacial Surgery, vol. 23, no. 1, pp. e36-e38, 2012.

[110] S. S. Doddamani, P. S. Handi, S. H. Chandrashekharayya, S. S. Suligavi, and S. S. Chougule, "Congential midline cervical cleft: a case report and an embryological review," Journal of Clinical and Diagnostic Research, vol. 6, no. 6, pp. 1086-1088, 2012.

[111] R. Méndez-Gallart, E. E. Martinez, P. Rodríguez-Barca, I. A. Nallib, and A. Bautista-Casasnovas, "Midline congenital cervical cleft mimicking linear scleroderma," Pediatric Dermatology, vol. 30, no. 4, pp. e34-e36, 2013. 
[112] X. Sinopidis, H. P. Kourea, A. Panagidis et al., "Congenital midline cervical cleft: diagnosis, pathologic findings, and early stage treatment," Case Reports in Pediatrics, vol. 2012, Article ID 951040, 5 pages, 2012.

[113] R.-B. Tröbs, C. Roll, S. Wirth, and M. Neid, "Midline cervical cleft in two toddlers: clinical presentation and surgical management," Klinische Padiatrie, vol. 224, no. 1, pp. 36-37, 2012.

[114] N. Martí Fajardo, C. Ortega Monzó, R. Tamarit Ortí, and R. Ibáñez Ramón, "Hendidura cervical media congénita," Piel, vol. 28, no. 2, pp. 122-123, 2013.

[115] C. Lillehei, "Neck cysts and sinuses," in Pediatric Surgery, A. Coran, Ed., chapter 59, pp. 753-761, Mosby, Philadelphia, Pa, USA, 7th edition, 2012.

[116] R. Farhadi, A. A. Sahebpour, and M. Ghasemi, "Congenital midline cervical cleft: can it be treated in newborn?" Iranian Journal of Pediatrics, vol. 22, no. 4, pp. 547-550, 2012.

[117] B. Mirza, "Congenital midline cervical cleft," APSP Journal of Case Reports, vol. 4, no. 1, p. 9, 2013.

[118] V. P. Saha, S. Pal, S. Saha, and S. Misra, "Congenital midline cervical cleft: a 7 year prospective study," Indian Journal of Otolaryngology and Head \& Neck Surgery, vol. 65, no. 4, pp. 367370, 2013.

[119] T. K. Eom, H. Sun, and H. K. Yoon, "Congenital midline cervical cleft," Archives of Plastic Surgery, vol. 41, no. 4, pp. 429-431, 2014.

[120] B. L. Crippa, M. F. Bedeschi, G. Cantarella et al., "A case of congenital midline cervical cleft: clinical approach to a congenital anterior neck defect," Congenital Anomalies, 2014.

[121] S. M. Houser and D. N. Traquina, "Pathologic quiz case," Archives of Otolaryngology-Head \& Neck Surgery, vol. 122, no. 6, pp. 680-682, 1996. 


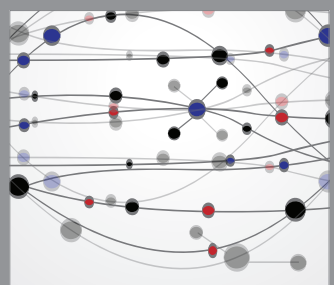

The Scientific World Journal
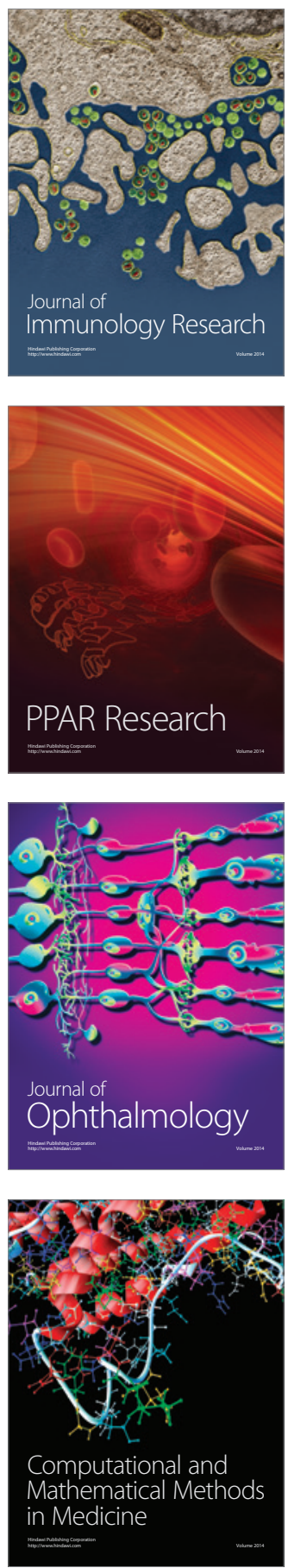

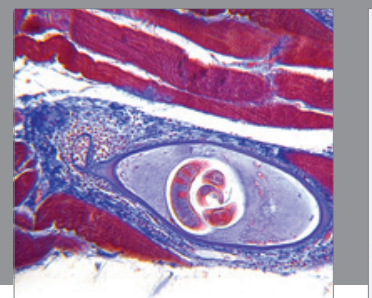

Gastroenterology

Research and Practice
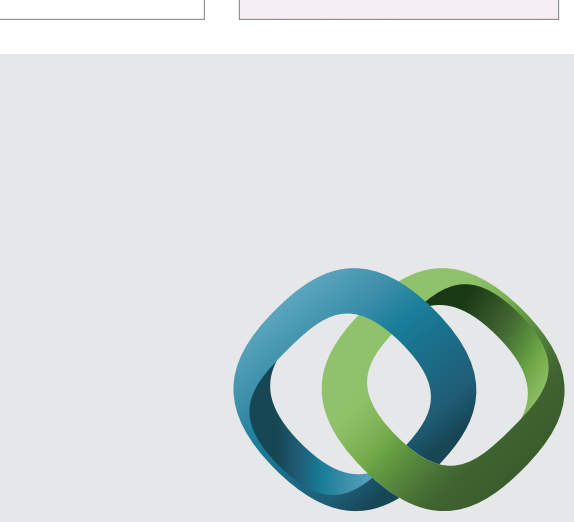

\section{Hindawi}

Submit your manuscripts at

http://www.hindawi.com
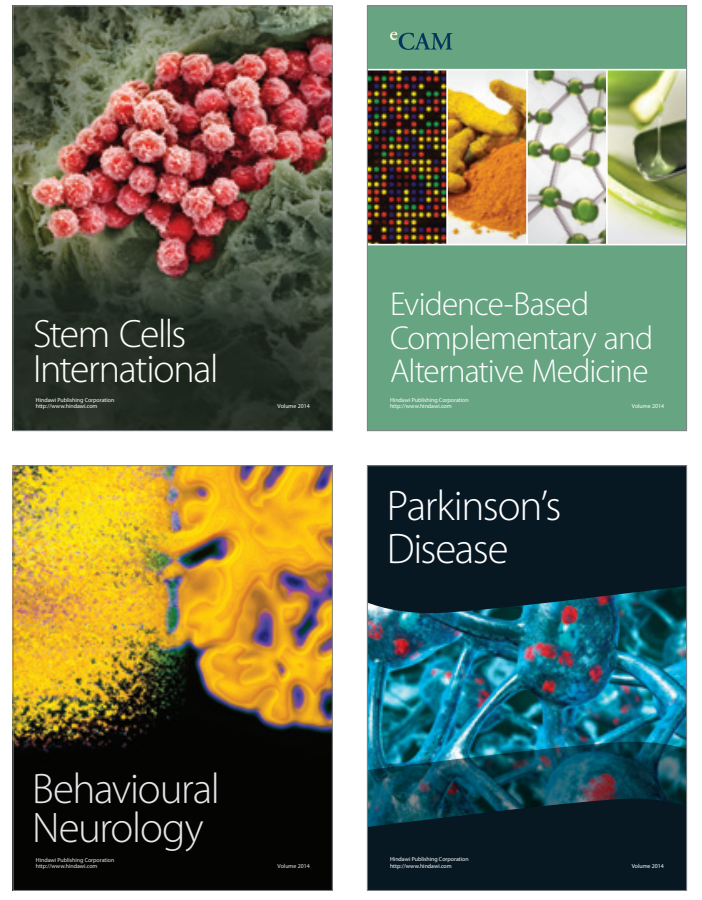
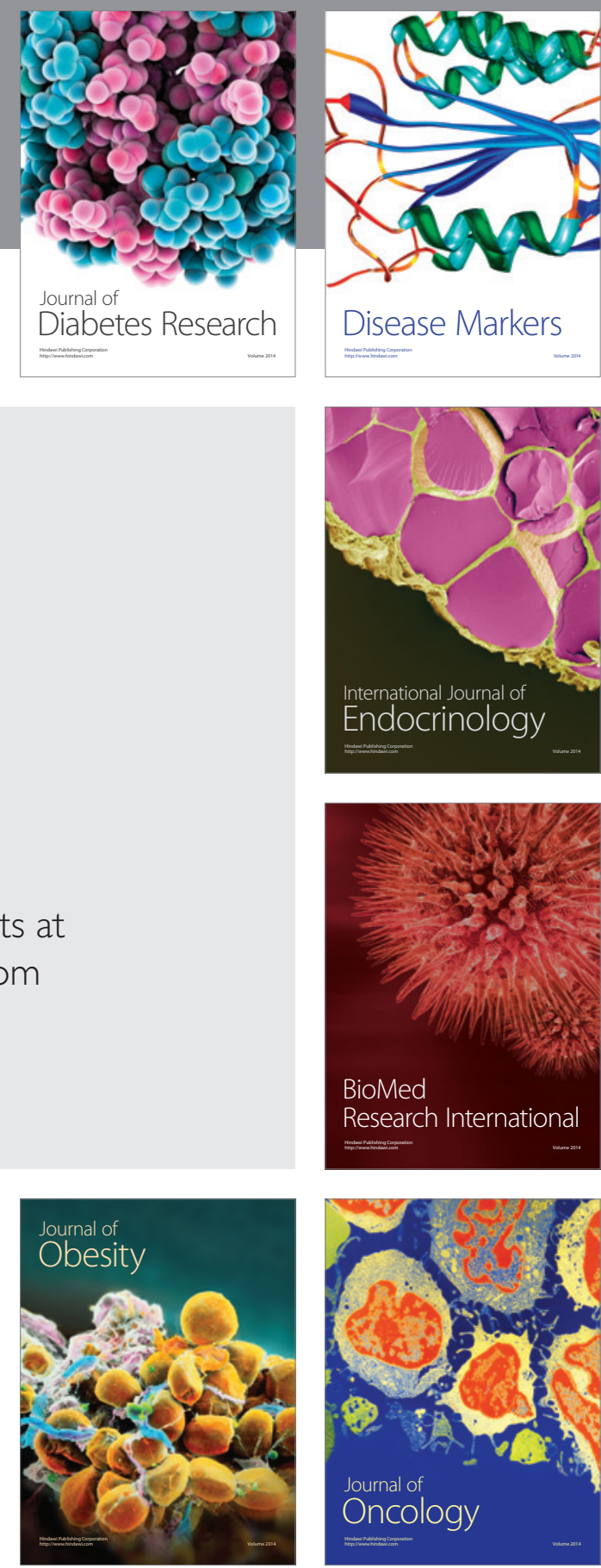

Disease Markers
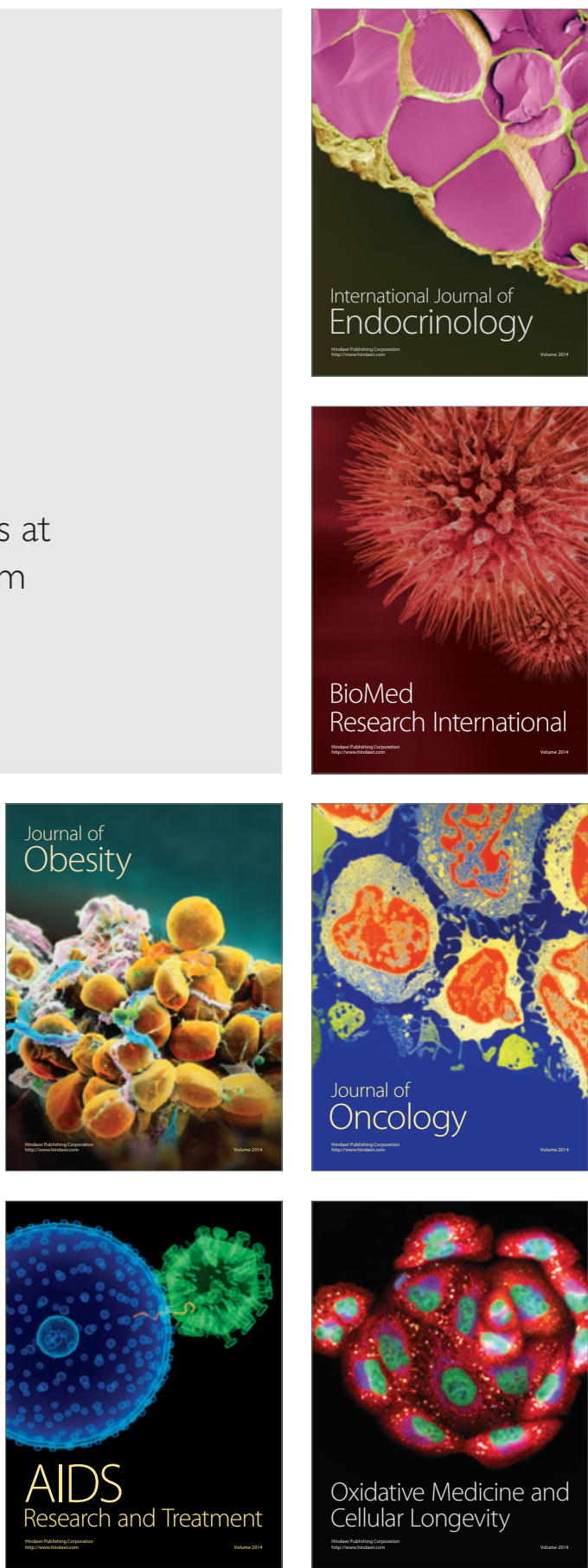